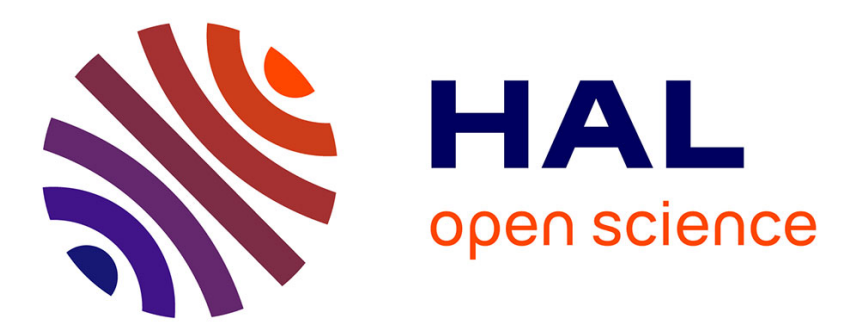

\title{
Cytotoxicity of metallic complexes of furan oximes in murine and human tissue cultured cell lines.
}

\author{
Iris H. Hall, Christian C. Lee, Ghassan Ibrahim, Mustayeen A. Khan, Gilles
}

M. Bouet.

\section{- To cite this version:}

Iris H. Hall, Christian C. Lee, Ghassan Ibrahim, Mustayeen A. Khan, Gilles M. Bouet.. Cytotoxicity of metallic complexes of furan oximes in murine and human tissue cultured cell lines.. Applied Organometallic Chemistry, 1997, 11 (7), pp.565-575. 10.1002/(SICI)1099-0739(199707)11:73.0.CO;2I . hal-03190047

\section{HAL Id: hal-03190047 \\ https://univ-angers.hal.science/hal-03190047}

Submitted on 8 Apr 2021

HAL is a multi-disciplinary open access archive for the deposit and dissemination of scientific research documents, whether they are published or not. The documents may come from teaching and research institutions in France or abroad, or from public or private research centers.
L'archive ouverte pluridisciplinaire $\mathbf{H A L}$, est destinée au dépôt et à la diffusion de documents scientifiques de niveau recherche, publiés ou non, émanant des établissements d'enseignement et de recherche français ou étrangers, des laboratoires publics ou privés. 


\title{
Cytotoxicity of Metallic Complexes of Furan Oximes in Murine and Human Tissue Cultured Cell Lines
}

\author{
Iris H. Hall, ${ }^{1 \star}$ Christian C. Lee, ${ }^{1}$ Ghassan Ibrahim, ${ }^{2}$ Mustayeen A. Khan ${ }^{2}$ and \\ Gilles M. Bouet ${ }^{2}$ \\ ' Division of Medicinal Chemistry and Natural Products, School of Pharmacy, University of North \\ Carolina, Chapel Hill, NC 27599-7360, USA \\ ${ }^{2}$ Laboratoire de Chimie de Coordination, Faculté de Pharmacie, 16 Boulevard Daviers, F-49100 \\ Angers, France
}

The copper complexes of furan oxime derivatives were found to be potent cytotoxic agents in both murine and human tissue cultured cell lines which were suspended as well as solid tumors. Mode of action studies in murine L1210 lymphoid leukemia cells showed that the compounds suppressed DNA, RNA and protein synthesis after $60 \mathrm{~min}$ at $100 \mu \mathrm{M}$. Inhibition of purine and pyrimidine de novo syntheses, as well as inhibition of ribonucleoside reductase and nucleoside kinase activities with DNA strand scission occurred. All of these effects of the drug probably added to its ability to cause cell death but most important was the inhibition of DNA topoisomerase III activity with $\mathbf{I C}_{50}$ values lower than those afforded by VP-16, the standard, which should cause apoptosis. (C) 1997 by John Wiley \& Sons, Ltd.

Appl. Organometal. Chem. 11, 565-575 (1997)

No. of Figures: 3 No. of Tables: 5 No. of Refs: 46

Keywords: complexes of furan oximes; IMP dehydrogenase; purine inhibitors; cytotoxicity; nucleic acid inhibitors

Received 4 July 1996; accepted 11 November 1996

\section{INTRODUCTION}

A series of metallic complexes of furan oximes have recently been synthesized. Based on the cytotoxicity of other copper, cobalt and iron metal complexes of trimethylamine carboxybor-

\footnotetext{
" Correspondence to: Iris H. Hall.
}

(1) 1997 by John Wiley \& Sons, Ltd. anes $^{1,2}$ and copper and nickel complexes of heterocyclic thiosemicarbazones ${ }^{3.4}$ we undertook a pilot study of the metal complexes of furan oximes to determine their ability to retard tumor cell growth in tissue culture cells. The previous complexes were unlike cis-platinum derivatives in that the agents were inhibitors of metabolic enzyme activities, e.g. purine regulatory enzymes, and DNA topoisomerase II. Inhibition of DNA topoisomerase II activity in human cancer cells by antineoplastic agents, e.g. etoposide (VP-16), has led to agents which have specificity for cancer cells and have a higher log kill of the cancer cells.

\section{MATERIALS AND METHODS}

\section{Source of compounds}

Synthesis of $\left.\left[\mathrm{CuCl}_{2} \text { (5-methyl-2-furaldehyde }\right)_{2}\right]$ (II) and [ $\mathrm{CuCl}_{2}$ [3-(2-furyl)prop-2-ene aldoxime $]_{2}$ ] (IIII) were conducted as previously described. $^{5,6}\left[\mathrm{CuCl}_{2} \text { (5-nitro-2-furaldehyde }\right)_{2}$ (II) and $\left[\mathrm{CuCl}_{2}[3\right.$-(2-furyl)prop-2-enal semicarbazone $]_{2}$ (IV) were obtained by reacting the ligand and copper chloride in stoichiometric amounts in refluxing anhydrous ethanol. ${ }^{7}$

All radioisotopes were purchased from New England Nuclear (Boston, MA, USA) unless otherwise indicated. Radioactivity was determined in Fisher Scintiverse scintillation fluid with correction for quenching. Substrates and cofactors were obtained from Sigma Chemical Co. (St Louis, MO, USA).

\section{Pharmacological mothods}

Compounds I-IV (Table 1) were tested for cytotoxic activity by homogenizing drugs in a 
Table 1. Cytotoxicity of metallic complexes of furan oximes

\begin{tabular}{|c|c|c|c|c|c|c|c|c|c|c|c|c|}
\hline \multirow[b]{2}{*}{ Compound $^{a}$} & \multicolumn{12}{|c|}{$\mathrm{ED}_{s 0}\left(\mu \mathrm{g} \mathrm{ml^{-1 }}\right)$} \\
\hline & $\begin{array}{c}\text { L1210 } \\
\text { leukemia }\end{array}$ & $\begin{array}{c}\text { Tmolt } \\
\text { leukemia }\end{array}$ & $\begin{array}{c}\text { HeLa- } \\
\mathrm{S}_{3} \\
\text { uterine }\end{array}$ & $\begin{array}{c}\text { HeLa } \\
\text { solid } \\
\text { uterine }\end{array}$ & $\begin{array}{l}\text { KB naso- } \\
\text { pharynx }\end{array}$ & $\begin{array}{l}\text { Skin } \\
\text { A431 }\end{array}$ & $\begin{array}{l}\text { Ileum } \\
\text { HCT-8 }\end{array}$ & $\begin{array}{l}\text { Colon } \\
\text { SW480 }\end{array}$ & $\begin{array}{l}\text { Lung } \\
\text { MB- } \\
9812\end{array}$ & $\begin{array}{l}\text { Lung } \\
\text { A549 }\end{array}$ & $\begin{array}{l}\text { UMR- } \\
106\end{array}$ & $\begin{array}{l}\text { Glioma } \\
\text { HS683 }\end{array}$ \\
\hline I & 2.42 & 5.19 & 2.03 & 3.81 & 0.61 & 4.26 & 9.85 & 2.98 & 3.56 & 5.06 & 4.26 & 6.83 \\
\hline II & 1.80 & 3.87 & 2.46 & 2.14 & 5.91 & 3.98 & 8.22 & 2.84 & 7.75 & 1.71 & 3.98 & 11.39 \\
\hline III & 2.98 & 4.63 & 2.01 & 8.69 & 2.54 & 2.93 & 2.43 & 4.16 & 8.05 & 1.80 & 2.91 & 7.66 \\
\hline IV & 1.53 & 3.61 & 1.55 & 9.27 & 4.53 & 8.44 & 3.45 & 3.31 & 8.25 & 2.50 & 8.44 & 8.40 \\
\hline $6 \mathrm{MP}^{\mathrm{a}}$ & 2.43 & 1.62 & 2.12 & 5.61 & 11.04 & 3.42 & 1.15 & 3.61 & 4.29 & 4.71 & 9.13 & 4.46 \\
\hline Ara-C $C^{b}$ & 2.41 & 2.67 & 2.13 & 4.74 & 2.84 & 0.92 & 2.54 & 3.42 & 6.16 & 6.28 & 0.86 & 1.88 \\
\hline Hydroxyurea & 2.67 & 4.47 & 1.96 & 8.12 & 5.27 & 3.21 & 1.77 & 7.33 & 7.18 & 8.89 & 2.87 & 2.27 \\
\hline $5-F U^{c}$ & 1.41 & 2.14 & 2.47 & 4.11 & 1.25 & 0.61 & 1.12 & 3.09 & 5.64 & 3.58 & 3.52 & 1.28 \\
\hline VP-16 & 1.83 & & 7.87 & 3.05 & 3.32 & 0.71 & 3.78 & 3.34 & 3.30 & 4.74 & 3.57 & 2.44 \\
\hline
\end{tabular}

abbreviations: 6MP, 6-mercaptopurine; Ara-C, cytidine arabinoside; 5-FU, 5-fluorouracil; VP-16, etoposide.

Table 2. Effects of $\left[\mathrm{CuCl}_{2}\left(5-\mathrm{NO}_{2}-2 \text { furaldehyde }\right)_{2}\right.$ (I) on $\mathrm{L} 1210$ leukemia cell metabolism over $60 \mathrm{~min}$

\begin{tabular}{|c|c|c|c|c|}
\hline \multirow[b]{2}{*}{ Assay $(n=6)$} & \multicolumn{4}{|c|}{ Percentage of Control $(x+S D)$} \\
\hline & Control & $25 \mu \mathrm{M}$ & $50 \mu \mathrm{M}$ & $100 \mu \mathrm{M}$ \\
\hline DNA synthesis & $100 \pm 5^{\mathrm{a}}$ & $88 \pm 5$ & $78 \pm 4 *$ & $52 \pm 3 *$ \\
\hline RNA synthesis & $100 \pm 6^{b}$ & $47 \pm 4^{*}$ & $35 \pm 3 *$ & $24 \pm 3 *$ \\
\hline Protein synthesis & $100 \pm 5^{c}$ & $93 \pm 5$ & $72 \pm 4 *$ & $46 \pm 3^{*}$ \\
\hline DNA polymerase $\alpha$ & $100 \pm 6^{d}$ & $96 \pm 6$ & $93 \pm 5$ & $88 \pm 6$ \\
\hline mRNA polymerase & $100 \pm 7^{e}$ & $153 \pm 5^{*}$ & $127 \pm 6^{*}$ & $104 \pm 5$ \\
\hline rRNA polymerase & $100 \pm 4^{f}$ & $70 \pm 4 *$ & $61 \pm 3 *$ & $59 \pm 4 *$ \\
\hline tRNA polymerase & $100 \pm 7^{8}$ & $83 \pm 6$ & $71 \pm 4^{*}$ & $61 \pm 4 *$ \\
\hline Ribonucleoside reductase & $100 \pm 5^{h}$ & $53 \pm 4 *$ & $26 \pm 4 *$ & $25 \pm 3^{*}$ \\
\hline Dihydrofolate reductase & $100 \pm 5^{i}$ & $106 \pm 7$ & $103 \pm 5$ & $67 \pm 4 *$ \\
\hline Purine de novo synthesis & $100 \pm 5^{j}$ & $114 \pm 6$ & $86 \pm 5$ & $6 \pm 2 *$ \\
\hline PRPP amido transferase & $100 \pm 6^{k}$ & $63 \pm 4 *$ & $48 \pm 3^{*}$ & $46 \pm 3^{*}$ \\
\hline IMP dehydrogenase & $100 \pm 5^{1}$ & $43 \pm 4 *$ & $25 \pm 4 *$ & $19 \pm 4 *$ \\
\hline Carbamoyl phosphate synthetase & $100 \pm 7^{m}$ & $88 \pm 6$ & $71 \pm 5 *$ & $58 \pm 5 *$ \\
\hline Aspartate transcarbamoylase & $100 \pm 6^{n}$ & $104 \pm 5$ & $80 \pm 5 *$ & $72 \pm 4 *$ \\
\hline Thymidylate synthase & $100 \pm 5^{\circ}$ & $44 \pm 5^{*}$ & $93 \pm 5$ & $92 \pm 5$ \\
\hline Thymidine kinase & $100 \pm 6^{p}$ & $118 \pm 6$ & $114 \pm 6$ & $117 \pm 6$ \\
\hline Thymidine monophosphate kinase & $100 \pm 7^{9}$ & $48 \pm 5 *$ & $46 \pm 5^{*}$ & $56 \pm 5 *$ \\
\hline Thymidine diphosphate kinase & $100 \pm 6^{r}$ & $44 \pm 3 *$ & $33 \pm 3 *$ & $52 \pm 4 *$ \\
\hline $\mathrm{d}(\mathrm{ATP})$ & $100 \pm 5^{s}$ & & & $67 \pm 4 *$ \\
\hline $\mathrm{d}(\mathrm{GTP})$ & $100 \pm 6^{t}$ & & & $91 \pm 5$ \\
\hline $\mathrm{d}(\mathrm{CTP})$ & $100 \pm 5^{u}$ & & & $139 \pm 6 *$ \\
\hline $\mathrm{d}(\mathrm{TTP})$ & $100 \pm 4^{v}$ & & & $96 \pm 5$ \\
\hline
\end{tabular}

Control values for $10^{6}$ cells $/ \mathrm{h}$ :

${ }^{2} 7719 \mathrm{dpm}$, ' $1014 \mathrm{dpm},{ }^{\mathrm{C}} 17492 \mathrm{dpm},{ }^{\mathrm{d}} 9019 \mathrm{dpm},{ }^{\circ} 1343 \mathrm{dpm},{ }^{\prime} 325 \mathrm{dpm}, 8400$ dpm, "48780 dpm, '0.144 O.D. units, j28624 dpm, '0.0878 O.D. units, '19575 dpm, m $0.807 \mathrm{~mol} N$-carbamoyl aspartate, $0.273 \mathrm{mmol}$ citrulline, $97616 \mathrm{dpm}$, p1371 dpm, ${ }^{9} 1179 \mathrm{dpm}$, '1891 dpm, "17.07 pmol, '13.58 pmol, "33.60 pmol, $31.04 \mathrm{pmol}$.

${ }^{*} P \leqslant 0.001$ (Student's $t$ test). 
$1 \mathrm{~mm}$ solution in $0.05 \%$ Tween $80 / \mathrm{H}_{2} \mathrm{O}$. These solutions were sterilized by passing them through an acrodisc filter $(0.45 \mu \mathrm{m})$. The following cell lines were obtained from American Type Culture Collection, Rockville, MD, USA, and maintained by literature techniques cited by the ATCC catalog: murine L1210 lymphoid leukemia, human Tmolt $_{3}$ acute lymphoblastic $\mathrm{T}$ cell leukemia, colorectal adenocarcinoma SW480, HCT-8 ileocecal adenocarcinoma, lung A549 carcinoma, lung bronchogenic MB-9812, rat osteosarcoma UMR-106, human KB epidermoid nasopharynx, epidermoid skin A431, HeLa-S ${ }^{3}$ suspended and solid cervical carcinoma and glioma EH $118 \mathrm{MG}$. The protocol of Geran et al. ${ }^{8}$ was used to assess the cytotoxicity of the compounds and standards in each cell line. Values for cytotoxicity were expressed as $\mathrm{ED}_{50}$ $\left(\mu \mathrm{g} \mathrm{ml}^{-1}\right)$, i.e. the concentration of the compound inhibiting $50 \%$ of cell growth. $\mathrm{ED}_{50}$ values were determined by the Trypan Blue exclusion technique. A value of less than $4 \mu \mathrm{g} \mathrm{ml}^{-1}$ was required for significant activity of growth inhibition. Solid tumor cytotoxicity was determined by the method of Liebovitz et al..$^{9}$ utilizing Crystal
Violet/MeOH, and read at $580 \mathrm{~nm}$ (Molecular Devices).

\section{Incorporation studies}

Incorporation of labeled precursors into $\left[{ }^{3} \mathrm{H}\right] \mathrm{DNA},\left[{ }^{3} \mathrm{H}\right] \mathrm{RNA}$ and $\left[{ }^{3} \mathrm{H}\right]$ protein for $10^{6}$ L1210 cells was determined. ${ }^{10}$ The concentration response at 25,50 and $100 \mu \mathrm{M}$ required for inhibition of DNA, RNA and protein syntheses was determined after $60 \mathrm{~min}$ incubations. The incorporation of $\left[{ }^{14} \mathrm{C}\right]$ glycine $\quad(53.0 \mathrm{mCi}$ $\mathrm{mmol}^{-1}$ ) into purines was obtained by the method of Cadman et al. ${ }^{11}$ Incorporation of $\left[{ }^{14} \mathrm{C}\right]$ formate $\left(53.0 \mathrm{mCi} \mathrm{mmol}^{-1}\right)$ into pyrimidines was determined by the method of Christopherson et al. ${ }^{12}$

\section{Enzyme assays}

Inhibition of various enzyme activities was performed by first preparing the appropriate L1210 cell homogenates or subcellular fractions, then adding the drug to be tested during the

Table 3. The effects of $\left.\left[\mathrm{CuCl}_{2} \text { (5-methyl-2-furaldehyde) }\right)_{2}\right]$ (II) on $\mathrm{L} 1210$ cell metabolism over $60 \mathrm{~min}$

\begin{tabular}{lcccc}
\hline & \multicolumn{3}{c}{ Percentage of control $(x+\mathrm{SD})$} \\
\cline { 2 - 5 } Assay $(n=6)$ & Control & $25 \mu \mathrm{M}$ & $50 \mu \mathrm{M}$ & $100 \mu \mathrm{M}$ \\
\hline DNA synthesis & $100 \pm 5$ & $84 \pm 5$ & $82 \pm 4^{*}$ & $52 \pm 3^{*}$ \\
RNA synthesis & $100 \pm 6$ & $30 \pm 3^{*}$ & $30 \pm 4^{*}$ & $30 \pm 3^{*}$ \\
Protein synthesis & $100 \pm 5$ & $66 \pm 4^{*}$ & $45 \pm 4^{*}$ & $35 \pm 3^{*}$ \\
DNA polymerase $\alpha$ & $100 \pm 6$ & $123 \pm 5^{*}$ & $74 \pm 5^{*}$ & $73 \pm 3^{*}$ \\
mRNA polymerase & $100 \pm 7$ & $120 \pm 6$ & $116 \pm 5$ & $93 \pm 5$ \\
rRNA polymerase & $100 \pm 4$ & $44 \pm 3^{*}$ & $38 \pm 3^{*}$ & $34 \pm 3^{*}$ \\
tRNA polymerase & $100 \pm 7$ & $127 \pm 6$ & $124 \pm 5^{*}$ & $83 \pm 6$ \\
Ribonucleoside reductase & $100 \pm 5$ & $79 \pm 6^{*}$ & $57 \pm 5^{*}$ & $52 \pm 5^{*}$ \\
Dihydrofolate reductase & $100 \pm 5$ & $62 \pm 4^{*}$ & $44 \pm 3^{*}$ & $16 \pm 3^{*}$ \\
Purine de novo synthesis & $100 \pm 5$ & $52 \pm 5^{*}$ & $30 \pm 4^{*}$ & $9 \pm 3^{*}$ \\
PRPP amidotransferase & $100 \pm 6$ & $51 \pm 4^{*}$ & $48 \pm 4^{*}$ & $25 \pm 3^{*}$ \\
IMP dehydrogenase & $100 \pm 5$ & $62 \pm 5^{*}$ & $48 \pm 6^{*}$ & $43 \pm 4^{*}$ \\
Carbamoyl phosphate synthetase & $100 \pm 7$ & $86 \pm 6$ & $70 \pm 4^{*}$ & $57 \pm 4^{*}$ \\
Aspartate transcarbamoylase & $100 \pm 6$ & $89 \pm 5$ & $73 \pm 5^{*}$ & $61 \pm 4^{*}$ \\
Thymidylate synthase & $100 \pm 5$ & $80 \pm 6$ & $93 \pm 6$ & $137 \pm 7^{*}$ \\
Thymidine kinase & $100 \pm 6$ & $119 \pm 6$ & $88 \pm 6$ & $42 \pm 4^{*}$ \\
Thymidine monophosphate kinase & $100 \pm 7$ & $94 \pm 6$ & $110 \pm 7$ & $86 \pm 5$ \\
Thymidine diphosphate kinase & $100 \pm 6$ & $118 \pm 6$ & $49 \pm 6^{*}$ & $51 \pm 4^{*}$ \\
d(ATP) & $100 \pm 5$ & & & $88 \pm 5$ \\
d(GTP) & $100 \pm 6$ & & & $110 \pm 5$ \\
d(CTP) & $100 \pm 5$ & & & $172 \pm 7^{*}$ \\
d(TTP) & $100 \pm 4$ & & & $131 \pm 6^{*}$ \\
\hline Contol & & & & \\
\hline
\end{tabular}

Control values are given in Table 2. 
enzyme assay. For the concentration response studies, inhibition of enzyme activity was determined at 25,50 and $100 \mu \mathrm{M}$ of compounds I-IV after $60 \mathrm{~min}$ incubations. DNA polymerase $\alpha$ activity was determined by cytoplasmic extracts isolated by the method of Eichler et al. ${ }^{13}$ Nuclear DNA polymerase $\beta$ was determined by isolating nuclei. ${ }^{14}$ The polymerase assay for both $\alpha$ and $\beta$ was described by Sawada et al. ${ }^{15}$ with $\left[{ }^{3} \mathrm{H}\right] \mathrm{TTP}$. Messenger-, ribosomal- and transfer-RNA polymerase enzymes were isolated with different concentrations of ammonium sulfate; individual RNA polymerase activities were determined using $\left[{ }^{3} \mathrm{H}\right]$ UTP. ${ }^{16,17}$ Ribonucleoside reductase activity was measured using $\left[{ }^{14} \mathrm{C}\right] \mathrm{CDP}$ with and without dithiothreitol. ${ }^{18}$ The deoxyribonucleotides $\left[{ }^{14} \mathrm{C}\right] \mathrm{dCDP}$ were separated from the ribonucleotides by TLC on polyethyleneimine (PEI) plates. Thymidine, TMP and TDP kinase activities were determined using $\left[{ }^{3} \mathrm{H}\right]$ thymidine $\left(58.3 \mathrm{mCi} \mathrm{mmol}^{-1}\right)$ in the medium of Maley and Ochoa. ${ }^{19}$ Carbamoyl phosphate synthetase activity was determined with the method of Kalman $e t$ al. $;^{20}$ citrulline was determined colorimetrically. ${ }^{21}$
Asparate transcarbamoylase activity was measured by the method of Kalman et al. $;^{20}$ carbamoyl aspartate was determined colorimetrically. ${ }^{22}$ Thymidylate synthetase activity was analyzed by the method of Kampf et al. ${ }^{23}$ The ${ }^{3} \mathrm{H}_{2} \mathrm{O}$ measured was proportional to the amount of TMP formed from $\left[{ }^{3} \mathrm{H}\right] \mathrm{dUMP}$. Dihydrofolate reductase activity was determined by the spectrophotometric method of Ho et al. ${ }^{24}$ PRPP amidotransferase activity was determined by the method of Spassova et al..$^{25}$ IMP dehydrogenase activity was analyzed with $8-\left[{ }^{14} \mathrm{C}\right] \mathrm{IMP}\left(54 \mathrm{mCi} \mathrm{mmol}^{-1}\right)$ (Amersham, Arlington Heights, IL, USA) after separating XMP on PEI plates (Fisher Scientific) by TLC. ${ }^{26}$ Protein content was determined for the enzymic assays by the Lowry technique. ${ }^{27}$

After deoxyribonucleoside triphosphates were extracted, ${ }^{28}$ levels were determined by the method of Hunting and Henderson ${ }^{29}$ with calf thymus DNA, E. coli DNA polymerase I, nonlimiting amounts of the three deoxyribonucleoside triphosphates not being assayed, and either $0.4 \mathrm{mCi}$ of $\left[{ }^{3} \mathrm{H}\right.$-methyl]dTTP or $\left[5-{ }^{3} \mathrm{H}\right] \mathrm{dCTP}$.

Table 4. The effects of $\left.\left[\mathrm{CuCl}_{2} \text { (3-2-furyl) prop-2-ene aldoxime) }\right]_{2}\right]$ (III) on L1210 cell metabolism over $60 \mathrm{~min}$

\begin{tabular}{|c|c|c|c|c|}
\hline \multirow[b]{2}{*}{ Assay $(n=6)$} & \multicolumn{4}{|c|}{ Percentage of control $(x+\mathrm{SD})$} \\
\hline & Control & $25 \mu \mathrm{M}$ & $50 \mu \mathrm{M}$ & $100 \mu \mathrm{M}$ \\
\hline DNA synthesis & $100 \pm 5$ & $125 \pm 6$ & $95 \pm 4$ & $45 \pm 3 *$ \\
\hline RNA synthesis & $100 \pm 6$ & $34 \pm 3^{*}$ & $31 \pm 3 *$ & $27 \pm 3^{*}$ \\
\hline Protein synthesis & $100 \pm 5$ & $39 \pm 4^{*}$ & $35 \pm 4^{*}$ & $26 \pm 4 *$ \\
\hline DNA polymerase $\alpha$ & $100 \pm 6$ & $93 \pm 5$ & $93 \pm 6$ & $71 \pm 5 *$ \\
\hline mRNA polymerase & $100 \pm 7$ & $70 \pm 5^{*}$ & $44 \pm 3 *$ & $39 \pm 3 *$ \\
\hline rRNA polymerase & $100 \pm 4$ & $115 \pm 6$ & $65 \pm 4^{*}$ & $37 \pm 4 *$ \\
\hline tRNA polymerase & $100 \pm 7$ & $126 \pm 7$ & $97 \pm 4$ & $77 \pm 5^{*}$ \\
\hline Ribonucleoside reductase & $100 \pm 5$ & $102 \pm 7$ & $81 \pm 5$ & $33 \pm 4 *$ \\
\hline Dihydrofolate reductase & $100 \pm 5$ & $108 \pm 6$ & $107 \pm 5$ & $98 \pm 6$ \\
\hline Purine de novo synthesis & $100 \pm 5$ & $95 \pm 7$ & $38 \pm 5^{*}$ & $22 \pm 3^{*}$ \\
\hline PRPP amidotransferase & $100 \pm 6$ & $106 \pm 5$ & $97 \pm 6$ & $80 \pm 4$ * \\
\hline IMP dehydrogenase & $100 \pm 5$ & $148 \pm 6^{*}$ & $11 \pm 4^{*}$ & $11 \pm 2 *$ \\
\hline Carbamoyl phosphate synthetase & $100 \pm 8$ & $64 \pm 4^{*}$ & $56 \pm 5 *$ & $45 \pm 3^{*}$ \\
\hline Aspartate transcarbamoylase & $100 \pm 6$ & $88 \pm 5$ & $71 \pm 5^{*}$ & $64 \pm 4 *$ \\
\hline Thymidylate synthase & $100 \pm 5$ & $99 \pm 6$ & $137 \pm 6^{*}$ & $168 \pm 9 *$ \\
\hline Thymidine kinase & $100 \pm 6$ & $86 \pm 5$ & $108 \pm 6$ & $111 \pm 6$ \\
\hline Thymidine monophosphate kinase & $100 \pm 7$ & $90 \pm 6$ & $68 \pm 5^{*}$ & $54 \pm 4^{*}$ \\
\hline Thymidine diphosphate kinase & $100 \pm 6$ & $77 \pm 6^{*}$ & $69 \pm 5^{\star}$ & $73 \pm 5^{*}$ \\
\hline $\mathrm{d}(\mathrm{ATP})$ & $100 \pm 5$ & & & $98+5$ \\
\hline$d(G T P)$ & $100 \pm 6$ & & & $107 \pm 7$ \\
\hline $\mathrm{d}(\mathrm{CTP})$ & $100 \pm 5$ & & & $172 \pm 9 *$ \\
\hline $\mathrm{d}(\mathrm{TTP})$ & $100 \pm 4$ & & & $110 \pm 6$ \\
\hline
\end{tabular}

Control values are given in Table 2. 
The effects of compounds I-IV on DNA strand scission were determined by the methods of Suzuki et al. ${ }^{30}$ Pera et al. ${ }^{31}$ and Woynarowski et al. ${ }^{32} \mathrm{~L} 1210$ leukemia cells were incubated with $10 \mu \mathrm{Ci}\left[{ }^{3} \mathrm{H}\right.$-methyl] thymidine $\left(84.0 \mathrm{Ci} \mathrm{mmol}^{-1}\right)$ for $24 \mathrm{~h}$ at $37^{\circ} \mathrm{C}$. L1210 cells $\left(10^{7}\right)$ were harvested and then centrifuged at $600 \mathrm{~g} \times 10 \mathrm{~min}$ in PBS. They were later washed and suspended in $1 \mathrm{ml}$ of PBS. Lysis buffer $(0.5 \mathrm{ml} ; 0.5 \mathrm{M}$ $\mathrm{NaOH}, 0.02 \mathrm{M}$ EDTA, $0.01 \%$ Triton $\mathrm{X}-100$ and $2.5 \%$ sucrose) was layered onto a 5-20\% alkaline sucrose gradient $(5 \mathrm{ml} ; 0.3 \mathrm{M} \mathrm{NaOH}, 0.7 \mathrm{M}$ $\mathrm{KCl}$ and $0.01 \mathrm{M}$ EDTA); this was followed by $0.2 \mathrm{ml}$ of the cell preparation. After the gradient had been incubated for $2.5 \mathrm{~h}$ at room temperature, it was centrifuged at $17500 \mathrm{rpm}$ at $20^{\circ} \mathrm{C}$ for $60 \mathrm{~min}$ (Beckman rotor SW60). Fractions $(0.2 \mathrm{ml})$ were collected from the bottom of the gradient, neutralized with $0.2 \mathrm{ml}$ of $0.3 \mathrm{M}$ $\mathrm{HCl}$, and measured for DNA radioactivity. Thermal calf thymus DNA denaturation studies, UV absorption studies and DNA viscosity studies were conducted after incubation of compounds I-IV at $100 \mu \mathrm{M}$ at $37^{\circ} \mathrm{C}$ for $24 \mathrm{~h} . .^{33}$

\section{Isolation of L-1210 topoisomerase II onzymo}

The procedure for isolating L1210 DNA topoisomerase II enzyme has been published previously. ${ }^{34}$ The isolated enzyme was used for the P4 phage DNA unknotting assay. Inhibition of the activity was noted as a smear of the DNA, e.g. unknotted DNA fragments in the gel, as opposed to DNA knotting at the top of the gel.

\section{DNA topoisomoraso II activity inhibition}

L1210 cells were pelleted and the DNA topoisomerase II enzyme was isolated from the nuclei as outlined by the published method of Liu et al ${ }^{35.36}$ The inhibition by compounds $\mathbb{I}-\mathbf{I V}$ from 1 to $100 \mu \mathrm{M}$ of DNA strand-passing activity was determined by a standard relaxation and unknotting assay for DNA topoisomerases. ${ }^{36}$ Briefly, the P4 knotted DNA was prepared from the phage heads of infected $E$. coli (C117) cells and was used as the substrate. The enzyme reaction contained a unit of DNA topoisomerase II [that

Table 5. The effects of [ $\mathrm{CuCl}_{2}$ (3-(2-furyl)prop-2-enal semicarbazone $\left.]_{2}\right]$ (IV) on L1210 nucleic acid metabolism after $60 \mathrm{~min}$

\begin{tabular}{lcccc}
\hline & \multicolumn{3}{l}{ Percentage of control $(x+\mathrm{SD})$} \\
\cline { 2 - 5 } Assay $(N=6)$ & Control & $25 \mu \mathrm{M}$ & $50 \mu \mathrm{M}$ & $100 \mu \mathrm{M}$ \\
\hline DNA synthesis & $100 \pm 5$ & $104 \pm 6$ & $113 \pm 6$ & $104 \pm 5$ \\
RNA synthesis & $100 \pm 6$ & $49 \pm 4^{*}$ & $47 \pm 4^{*}$ & $20 \pm 3^{*}$ \\
Protein synthesis & $100 \pm 5$ & $128 \pm 6$ & $89 \pm 5$ & $73 \pm 4^{*}$ \\
DNA polymerase $\alpha$ & $100 \pm 6$ & $88 \pm 6$ & $87 \pm 6$ & $86 \pm 5$ \\
mRNA polymerase & $200 \pm 7$ & $88 \pm 6$ & $64 \pm 4^{*}$ & $57 \pm 4^{*}$ \\
rRNA polymerase & $100 \pm 4$ & $125 \pm 5^{*}$ & $68 \pm 5^{*}$ & $52 \pm 3^{*}$ \\
tRNA polymerase & $100 \pm 7$ & $79 \pm 5^{*}$ & $51 \pm 3^{*}$ & $23 \pm 3^{*}$ \\
Ribonucleoside reductase & $100 \pm 5$ & $78 \pm 4^{*}$ & $69 \pm 5^{*}$ & $44 \pm 4^{*}$ \\
Dihydrofolate reductase & $100 \pm 5$ & $107 \pm 6$ & $118 \pm 5$ & $102 \pm 6$ \\
Purine de novo synthesis & $100 \pm 5$ & $93 \pm 5$ & $36 \pm 3^{*}$ & $6 \pm 2^{*}$ \\
PRPP amidotransferase & $100 \pm 6$ & $115 \pm 5$ & $114 \pm 6$ & $118 \pm 6$ \\
IMP dehydrogenase & $100 \pm 5$ & $114 \pm 5$ & $52 \pm 3^{*}$ & $40 \pm 4^{*}$ \\
Carbamoyl phosphate synthetase & $100 \pm 7$ & $92 \pm 5$ & $79 \pm 6^{*}$ & $71 \pm 5^{*}$ \\
Aspartate transcarbamoylase & $100 \pm 6$ & $83 \pm 6$ & $74 \pm 4^{*}$ & $65 \pm 3^{*}$ \\
Thymidylate synthase & $100 \pm 5$ & $79 \pm 6^{*}$ & $89 \pm 7$ & $127 \pm 5^{*}$ \\
Thymidine kinase & $100 \pm 6$ & $70 \pm 6^{*}$ & $61 \pm 5^{*}$ & $65 \pm 6^{*}$ \\
Thymidine monophosphate kinase & $100 \pm 7$ & $140 \pm 6$ & $81 \pm 7$ & $68 \pm 5^{*}$ \\
Thymidine diphosphate kinase & $100 \pm 6$ & $82 \pm 5$ & $62 \pm 5^{*}$ & $51 \pm 5^{*}$ \\
d(ATP) & $100 \pm 5$ & & & $88 \pm 6$ \\
d(GTP) & $100 \pm 6$ & & & $109 \pm 5$ \\
d(CTP) & $100 \pm 5$ & & & $178 \pm 7^{*}$ \\
d(TTP) & $100 \pm 4$ & & & $100 \pm 4$ \\
\hline Control & & & & \\
\hline
\end{tabular}

Control values are given in Table 2. 
amount which catalyzed the unknotting of $0.2 \mu \mathrm{g}$ of P4 DNA] in $20 \mu \mathrm{l}$ of $50 \mathrm{~mm}$ Tris- $\mathrm{HCl} \mathrm{pH} 7.5$ buffer, $100 \mathrm{mM} \mathrm{KCl}, 10 \mathrm{mM} \mathrm{MgCl}_{2}, 0.5 \mathrm{~mm}$ DTT, $0.5 \mathrm{mM} \mathrm{Na}_{3}$ EDTA, BSA $\left(30 \mu \mathrm{g} \mathrm{ml}^{-1}\right)$ and $1 \mathrm{~mm}$ ATP. The reaction was incubated for $60 \mathrm{~min}$ at $37^{\circ} \mathrm{C}$ and then was stopped by adding $5 \mu \mathrm{l}$ of $5 \%$ SDS (w/v), $50 \mathrm{~mm} \mathrm{Na}$ EDTA, $20 \%$ sucrose (w/v), and $0.05 \mathrm{mg} \mathrm{ml}^{-1}$ Bromophenol Blue. The reaction product was analyzed on $0.7 \%(\mathrm{w} / \mathrm{v})$ agarose gel in $89 \mathrm{~mm}$ Tris-borate buffer, pH 8.2+2 mM Na $\mathrm{EDTA}$, electrophoresed at $23 \mathrm{~V}$ for $18 \mathrm{~h}$, and then stained with ethidium bromide. The $\mathrm{IC}_{50}$ values for inhibition by the compounds were determined using a densitometer, and a photograph of the gel [Fig. 2] with UV at $300 \mathrm{~nm}$ illumination was taken, as permanent records. Photographs were obtained with Polaroid Type 667 film. IC $_{50}$ values were determined by plotting the log of the concentration of the compounds versus the percentage of enzyme activity.

\section{Cleavage-interference in L1210 cells}

Whole L1210 cells or prepared nuclei from cells in log growth were pre-labeled with $\left[{ }^{3} \mathrm{H}\right]$ thymi-



Figure 1 L1210 DNA strand scission after $24 \mathrm{~h}$ incubation with compounds I-IV or no drug (control). dine (60-90 Ci mmol-1, NEN) for $24 \mathrm{~h}$. The reaction medium $(250 \mu l)$ contained whole cells or isolated nuclei in buffer supplemented with $3 \mathrm{~mm}$ ATP and compounds $\mathbb{I}-\mathbb{I V}$ at $100 \mu \mathrm{M}$ for $60 \mathrm{~min}$. Additional tubes were incubated with VP-16 at $40 \mu \mathrm{M}$ for an additional $60 \mathrm{~min}$ with and without the compounds. After incubation at $37^{\circ} \mathrm{C}$, cells or nuclei were collected by centrifugation $[500 \mathrm{~g} \times 2 \mathrm{~min}]$ and analyzed for protein-linked DNA breaks by the method detailed by Rowe et al..$^{37}$ and counted.

Phosphorylation of the isolated L1210 DNA topoisomerase II enzyme was measured by the method of DeVore et al..$^{38}$ using $\left[\gamma^{32} \mathrm{P}\right]$ ATP $\left(3000 \mathrm{Ci} \mathrm{mmol}^{-1}\right.$ ) (Dupont) for 30 to $60 \mathrm{~min}$. The reaction was inactivated by $10 \%$ trichloroacetic acid (TCA) and filtered on GF/A glass-fiber filters and counted. Standard protein kinase $\mathrm{C}$ inhibitors, $\mathrm{A}_{3}$ and bisindolylmaleimide (Calbiochem-Novabiochem) were also used.

\section{Statistics}

The mean and standard deviation are designated by $x \pm \mathrm{SD}$. The probable level of significance $(P)$ between test and control samples were deter- 
mined by Student's $t$ test or Dunnett's test with the raw data.

\section{RESULTS}

The metallic complexes of furan oximes proved to be potent cytotoxic agents (Table 1). In mouse L1210 lymphoid leukemia cells, compounds IIV afforded $\mathrm{ED}_{50}$ values less than $3 \mu \mathrm{g} \mathrm{ml}^{-1}$ (Table 1) with compounds II and IV exhibiting the best activity with $\mathrm{ED}_{50}$ values of 1.8 and $1.53 \mu \mathrm{g} \mathrm{ml}^{-1}$, respectively. Tmolt $_{3}$ leukemia growth was inhibited only by compound IV with an $\mathrm{ED}_{50}$ value of $3.61 \mu \mathrm{g} \mathrm{ml}^{-1}$. HeLa-S ${ }^{3}$ suspended uterine cell growth was inhibited by compounds I-IV with $\mathrm{ED}_{50}$ values from 2.46 to $1.55 \mu \mathrm{g} \mathrm{ml}^{-1}$. Compounds I and II were active against solid $\mathrm{HeLa}$ uterine carcinoma growth with $\mathrm{ED}_{50}$ values of 3.81 and $2.14 \mu \mathrm{g} \mathrm{ml}^{-1}$, respectively. The colon adenocarcinoma growth was reduced by compounds I, II and IV with $\mathrm{ED}_{50}$ values from 3.31 to $2.84 \mu \mathrm{g} \mathrm{ml}^{-1}$. HCT-8 ileum carcinoma growth was inhibited by compounds II and IV with $\mathrm{ED}_{50}$ values of 2.43 and $3.45 \mu \mathrm{g} \mathrm{ml}^{-1}$. KB nasopharynx carcinoma growth was markedly reduced by compound II with an $\mathrm{ED}_{50}$ value of $0.61 \mu \mathrm{g} \mathrm{ml}^{-1}$ and moderately by compound III with an $\mathrm{ED}_{50}$ value of $2.54 \mu \mathrm{g} \mathrm{ml}^{-1}$. Skin A431 epidermoid growth was reduced by compounds III and III with $\mathrm{ED}_{50}$ values 3.98 and $2.93 \mu \mathrm{g} \mathrm{ml}^{-1}$, respectively. Lung A549 growth was markedly reduced by compounds II, III and IV with $\mathrm{ED}_{50}$ values of

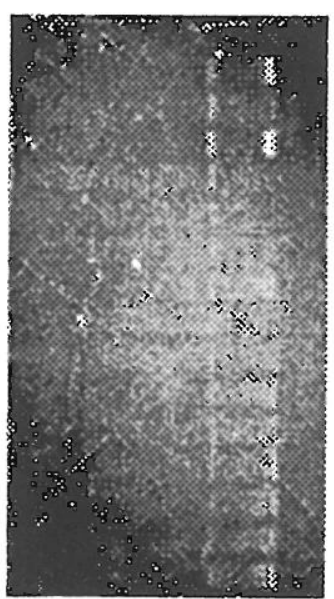

Cmpd I

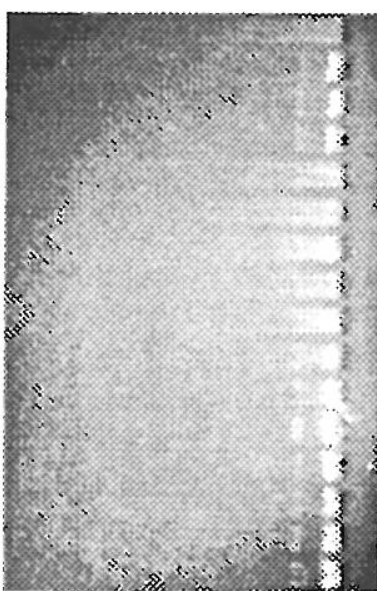

Cmpd III

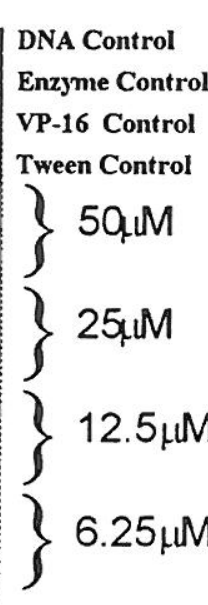

VP-16 Control

Tween Control

$5 a_{1 M}$

25, M

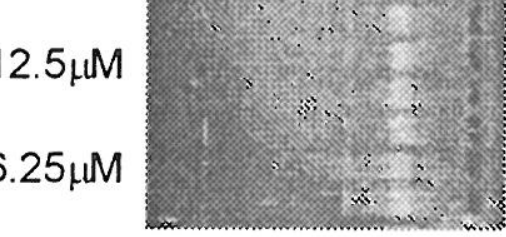

Cmpd II

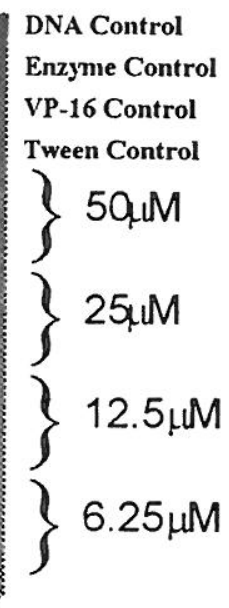

Enzyme Control

VP-16 Control

Tween Control

5quM

$25 \mathrm{M}$

$12.5 \mu \mathrm{M}$

$6.25 \mu \mathrm{M}$ 


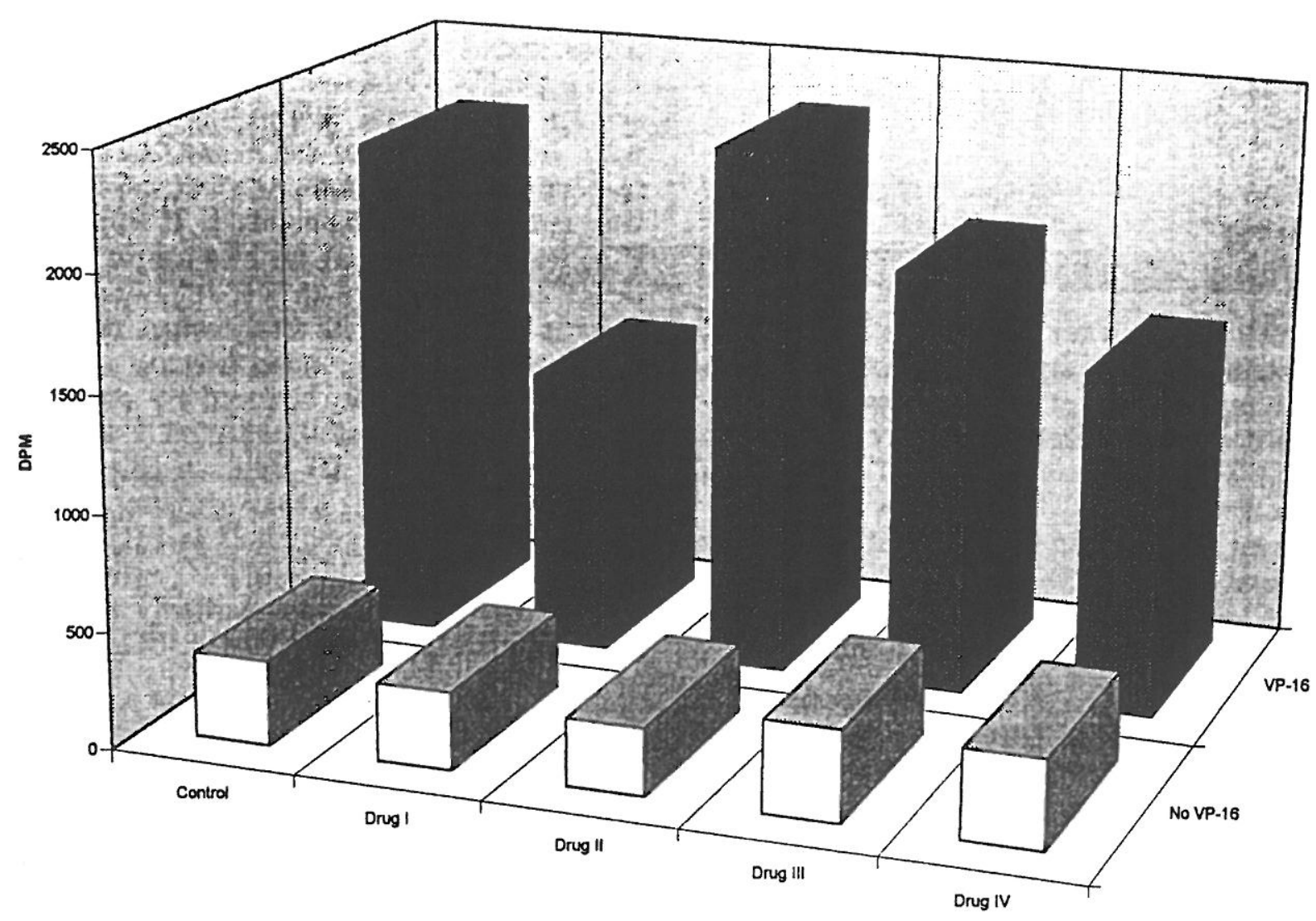

Figure 3 DNA protein-linked breaks

$1.71,1.80$ and $2.50 \mu \mathrm{g} \mathrm{ml}^{-1}$, respectively, but lung MB-9812 growth was only reduced by compound I with an $\mathrm{ED}_{50}$ value of $3.56 \mu \mathrm{g} \mathrm{ml}^{-1}$. Human brain glioma solid cell growth was not inhibited significantly by any of the compounds, with $\mathrm{ED}_{50}$ values greater than $4 \mu \mathrm{g} \mathrm{ml}^{-1}$. Rat osteosarcoma growth was affected only by compounds III and III with $\mathrm{ED}_{50}$ values of 3.98 and $2.91 \mu \mathrm{g} \mathrm{ml}^{-1}$, respectively.

A mode-of-action study was conducted with the four compounds in the L1210 lymphoid leukemia tissue culture model (Tables 2-5). Compounds I-III inhibited DNA synthesis in a concentration-dependent manner (approximately $50 \%$ at $100 \mu \mathrm{M}$ ). RNA synthesis was actually reduced more significantly (approximately $70 \%$ at $100 \mu \mathrm{M}$ after $60 \mathrm{~min}$ ) and protein synthesis was reduced $54 \%, 65 \%, 74 \%$ and $27 \%$ respectively by compounds I-IV. DNA polymerase alpha activity was marginally inhibited 12-29\% by the four compounds at $100 \mu \mathrm{M}$. mRNA polymerase activity was reduced only by compounds III and IV, affording $61 \%$ and $43 \%$ reduction at $100 \mu \mathrm{M}$ after $60 \mathrm{~min}$, whereas rRNA polymerase activity was reduced by all four compounds in a concentration-dependent manner with $41-66 \%$ reduction at $100 \mu \mathrm{M}$. t-RNA polymerase activity was reduced significantly by compounds I and IV with $39 \%$ and $77 \%$ reduction at $100 \mu \mathrm{M}$. Ribonucleoside reductase activities were moderately reduced by $48-75 \%$, with compounds I and IV affording the best activity. Dihydrofolate reductase activity was reduced $33 \%$ at $100 \mu \mathrm{M}$ concentration by compound I and $84 \%$ by compound III. Purine de novo synthesis was significantly reduced by $78 \%$ by compound III whereas compounds I, II and IV caused greater than $90 \%$ reduction. Phosphoribosyl pyrophosphate (PRPP) amidotransferase activity was significantly inhibited by $54 \%, 75 \%$ and $20 \%$ at $100 \mu \mathrm{M}$, respectively for compounds I, II and III. IMP dehydrogenase activity was inhibited $57-89 \%$, with compounds I and IV resulting in greater than $80 \%$ reduction. The pyrimidine de novo synthetic pathway was inhibited significantly: carbamoyl phosphate synthetase activity was reduced in a concentration-dependent manner with $29-55 \%$ reduction at $100 \mu \mathrm{M}$ after $60 \mathrm{~min}$, and aspartate transcarbamoylase activity was inhibited $28-39 \%$ at $100 \mu \mathrm{M}$ after $60 \mathrm{~min}$. Thymidylate synthetase activity was actually stimulated slightly by 
compounds II-IV. Thymidine kinase activity was reduced $58 \%$ and $35 \%$ by compounds II and IV, respectively, but compounds I and III had no effect. TMP kinase activity was reduced $14-46 \%$ by the agents. TDP kinase activity was reduced $48-49 \%$ by compounds I, II and IV but only $27 \%$ by compound III. d(CTP) Pool levels were elevated $39-78 \%$ after 60 min incubation with all four compounds at $100 \mu \mathrm{M}$; however, $\mathrm{d}(\mathrm{TTP})$ and $d(G T P)$ levels were not affected at $100 \mu \mathrm{M}$ concentrations of the agents.

Incubation of compounds I-IV at $100 \mu \mathrm{M}$ for $24 \mathrm{~h}$ with ctDNA showed that a maximum absorption of ctDNA shifted to a lower wavelength in the UV absorption range with an increased absorption occurring. $T_{\mathrm{m}}$ values for thermal denaturation of ctDNA demonstrated values less than the control ctDNA values. ctDNA viscosity studies indicated less time necessary to move ctDNA through the reservoirs than for the control ctDNA. However, incubation of compounds I-IV with L1210 cells for $24 \mathrm{~h}$ resulted in DNA fragmentation (Fig. 1) since more of the radioactivity appeared in fraction numbers higher in gradient rather than doublestranded DNA at the bottom of the gradient (fraction 1). L1210 topoisomerase II activity was significantly inhibited by compounds I-IV with $\mathrm{IC}_{50}$ values of $15.4,23.5,21.5$ and $15.5 \mu \mathrm{M}$, respectively (Fig. 2). These $\mathrm{IC}_{50}$ values were better than for VP-16, which afforded an $\mathrm{IC}_{50}$ value of $25.5 \mu \mathrm{M}$. L1210 DNA protein-linked breaks were not produced by the agents when used alone for $1 \mathrm{~h}$ (front row), nor did they increase those DNA protein-linked breaks afforded by VP-16 at $40 \mu \mathrm{M} / \mathrm{control}$ (back row) after another $1 \mathrm{~h}$ incubation (Fig. 3). In fact compound I attenuated the DNA protein-linked breaks caused by VP-16 and compounds $I I$ and IV were moderately effective in reducing breaks produced by VP-16. These data suggest that the copper complexes do have the same mechanism of inhibiting DNA topoisomerase $I I$ as the standard VP-16 which produces a cleavable DNA product.

Protein kinase $\mathrm{C}$ phosphorylation of the isolated L1210 DNA topoisomerase II enzyme was reduced after $30 \mathrm{~min}$ by $93 \%, 97 \%, 99 \%$ and $97 \%$ and after $60 \mathrm{~min}$ by $88 \%, 89 \%, 83 \%$ and $89 \%$ by compounds I, II, III and IV, respectively, at $100 \mu \mathrm{M}$. The standards $\mathrm{A}_{3}$ at $100 \mu \mathrm{M}$ caused $23 \%$ reduction of phosphorylation and bisindolylmaleimide at $20 \mathrm{~nm}$ caused $85 \%$ reduction at $30 \mathrm{~min}$. After $2 \mathrm{~h}$ incubation, there was a
$34 \%$ reduction for $\mathrm{A}_{3}$ and a $64 \%$ reduction for bisindolylmaleimide.

\section{DISCUSSION}

The metallic complexes of furan oximes proved to be potent cytotoxic agents in human and murine tissue culture cell lines. Not only were the four derivatives active against the growth of suspended cell lines but also produced $E_{50}$ values of $<4 \mu \mathrm{g} \mathrm{ml}^{-1}$ against the growth of solid human tumors. For example, compound III was active against the growth of human $\mathrm{KB}$ nasopharynx, skin A431 epidermoid, ileum HCT-8, and lung A549 carcinomas and rat UMR-106 osteosarcoma. On the other hand, compounds I, II and IV were active in the SW480 colon adenocarcinoma screen. These new compounds were as active as clinically useful standards. Mode-of-action studies in L1210 lymphoid leukemia cells demonstrated that the four compounds were metabolic inhibitors. The compounds preferentially inhibited DNA and RNA synthesis principally because the agents were very effective in blocking purine de novo synthesis. All of the agents inhibited IMP dehydrogenase activity significantly and two compounds also reduced PRPP amidotransferase activity. By blocking the two regulatory enzyme activities in the purine pathway, then, the reduction in nucleic acid synthesis would be expected. Other sites that the agents inhibited were ribonucleoside reductases which would lower d(NTP) pool levels converted from r(NTP)s. Two of the compounds reduced dihydrofolate reductase activity which would reduce one carbon transfer for purine and pyrimidine synthesis. Enzyme activities in the pyrimidine pathway, e.g. carbamoyl phosphate, aspartate transcarbamoylase and thymidylate synthetase, were only moderately effected by the agents, and certainly not by a magnitude to justify the observed reduction of nucleic acids in $60 \mathrm{~min}$. The nucleic kinase enzyme activities were reduced by the agents. Since DNA polymerase $\alpha$ activity was moderately reduced by the agents, there was no observable reduction in nucleotide pools because the deoxynucleotides were not being incorporated into new strands of DNA, but were accumulating inside the cell. rRNA and tRNA polymerase activities were reduced by the compounds but mRNA polymerase activity was not 
always inhibited. The reduction in these polymerase activities would add to the overall reduction of RNA synthesis.

ctDNA studies demonstrated that there was no increase in DNA viscosity after incubating drugs with ctDNA after $24 \mathrm{~h}$, indicating no crosslinking. However, the hyperchromic shift of the UV-absorption of ctDNA to a lower wavelength and the alteration of $T_{m}$ values in the thermal denaturation studies indicate some type of interaction with the DNA bases. L1210 studies in which the drug was incubated for $24 \mathrm{~h}$ demonstrated that DNA strand scission was evident with each of the agents at $100 \mu \mathrm{M}$. This finding is consistent with the observed reduction in ctDNA viscosity after $24 \mathrm{~h}$ incubation with the agents at $100 \mu \mathrm{M}$.

Most important was that these copper complexes inhibited L1210 DNA topoisomerase II activity better than the clinical agent etoposide (VP-16). Agents which are topoisomerase II inhibitors usually have high cytotoxic action. Some topoisomerase II inhibitors cause DNA protein-linked breaks, e.g. epipodophyllotoxins, amsacrine, doxorubicin, ellipticine ${ }^{39}$ and metal complexes of trimethylamine carboxyborane, ${ }^{40}$ whereas others kill the cell by inhibiting DNA topoisomerase II activity by another mechanism, e.g. merbarone, ${ }^{41}$ aciarubicin, bis(2,6-dioxopiperazine)s, ${ }^{42}$ fostriecin ${ }^{43.44}$ and metal complexes of thiosemicarbazones. ${ }^{45}$ Phosphorylation of DNA topoisomerase II by protein kinases maintains the enzyme in the highest catalytic state. Agents which block the phosphorylation of the topoisomerase enzyme are linked with more DNA fragmentation and cell death. ${ }^{40,46}$

\section{REFERENCES}

1. I. H. Hall, B. F. Spielvogel and A. T. McPhail, J. Pharm. Sci. 73, 222 (1984).

2. I. H. Hall, K. W. Morse, B. F. Spielvogel and A. Sood, Anti-Cancer Drugs 2, 389 (1991).

3. D. X. West, A. E. Liberta, K. G. Rajendran and I. H. Hall, Anti-Cancer Drugs 4, 231 (1993).

4. D. X. West, K. G. Rajendra, A. E. Liberta and I. H. Hall, Anti-Cancer Drugs 4, 241 (1993).

5. G. Bouet and J. Dugue, Transition Met. Chem. 14, 351 (1989).

6. G. Bouet, J. Dugue and F. Keller-Besest, Transition Met. Chem. 15, 5 (1990).

7. G. Bouet, M. A. Khan and G. Ibrahim, results to be published.
8. R. J. Geran, N. H. Greenburg, M. M. MacDonald, A. M. Schumacher and B. J. Abbott, Cancer Chemother. Rep. 3, 9 (1972).

9. A. L. Leibovitz, J. C. Stinson, W. B. McComb III, C. E. McCoy, K. C. Mazur and N. D. Mabry, Cancer Res. 36, 4562 (1976).

10. L. L. Liao, S. M. Kupchan and S. B. Horwitz, Mol. Pharmacol. 12, 167 (1976).

11. E. Cadman, R. Heimer and C. Benz, J. Biol. Chem. 256, 1695 (1981).

12. R. I. Christopherson, M. L. Yu and M. E. Jones, Anal. Biochem. 11, 240 (1981).

13. D. C. Eichler, P. A. Fisher and D. Korn, J. Biol. Chem. 252, 4011 (1977).

14. F. P. Mamaril, A. Dobrjasky and S. Green, Cancer Res. 30, 352 (1970).

15. H. Sawada, K. Tatsumi, M. Sadada, S. Shirakawa, T. Nakamura and G. Wakisaka, Cancer Res. 34, 3341 (1974).

16. K. M. Anderson, I. S. Mendelson and G. Guzik, Biochem. Biophys. Acta 383, 56 (1975).

17. I. H. Hall, G. L. Carlson, G. S. Abernathy and C. Piantadosi, J. Med. Chem. 17, 1253 (1974).

18. E. C. Moore and R. B. Hurlbert, J. Biol. Chem. 241, 4802 (1966).

19. F. Maley and S. Ochoa, J. Biol. Chem. 233, 1538 (1958).

20. S. M. Kalman, P. H. Duffield and T. J. Brzozwki, J. Biol. Chem. 241, 1871 (1966).

21. R. M. Archibald, J. Biol. Chem. 156, 121 (1944).

22. S. B. Koritz and P. P. Gohen, J. Biol. Chem 209, 145 (1954).

23. A. Kampf, R. L. Barfknecht, P. J. Schaffer, S. Osaki and M. P. Mertes, J. Med. Chem. 19, 903 (1976).

24. Y. K. Ho, T. Hakala and S. F. Zakrzewski, Cancer Res. 32, 1023 (1971).

25. M. K. Spassova, G. C. Russev and E. V. Goovinsky, Biochem. Pharmacol. 25, 923 (1976).

26. J. H. Becker and G. W. Lohr, Klin. Wochenschr. 57 , 1109 (1979).

27. O. H. Lowry, J. Rosebrough, A. L. Farr and R. J. Randall, J. Biol. Chem. 193, 265 (1951).

28. A. S. Bagnara and L. R. Finch, Anal. Biochem. 45, 24 (1971).

29. D. Hunting and J. F. Henderson, Can. J. Biochem. 59, 723 (1982).

30. H. Suzuki, T. Nishimura, S. K. Muto and N. Tanaka, J. Antibacteriol. 32, 875 (1978).

31. J. F. Pera Sr, C. J. Rawlings, J. Shackleton and J. J. Roberts, Biochem. Biophys. Acta 655, 152 (1981).

32. J. W. Woynarowski, T. A. Beerman and J. Konopa, Biochem. Pharmacol. 30, 3005 (1981).

33. Y. Zhao, I. H. Hall, C. B. Oswald, T. Yokoi and K. H. Lee, Chem. Pharm. Bull. 35, 2052 (1987).

34. L. F. Liu and J. L. Davis, Nucleic Acid Res. 9, 3979 (1981).

35. L. F. Liu, T. C. Rowe, L. Yang, K. M. Tewey and G. L. Chen, J. Biol. Chem. 258, 15365 (1983).

36. L. F. Liu, J. D. Davis and R. Calendra, Nucleic Acid 
Res. 9, 3979 (1981).

37. T. C. Rowe, G. L. Chen, Y. H. Hsiang and L. F. Liu, Cancer Res. 46, 2021 (1986).

38. R. F. DeVore, A. H. Corbett and N. Osheroff, Cancer Res. 52, 2156 (1992).

39. K. M. Rose, FASEB J. 2, 2474 (1988).

40. M. C. Miller III, Ph.D. Thesis, University of North Carolina, 1996.

41. G. Rappa, A. Lorico and A. C. Sartorelli, Int. J. Cancer 51, 78 (1992).

42. M. A. Del Bino, P. Lassota, F. Traganos and Z.
Darzynkiewicz, Cancer Res. 52, 1530 (1992).

43. K. Tnabe, Y. Ikegami, R. Ishida and T. Andoh, Cancer Res, 51, 4903 (1991).

44. T. J. Boritzki, T. S. Wolfard, J. A. Besserer, R. C. Jackson and D. W. Fry, Biochem. Pharmacol. 37, 4063 (1988).

45. M. C. Miller III, K. F. Bastow, C. N. Stineman, J. R. Vance, S. C. Song, D. X. West and I. H. Hall, Metal Based Drugs, submitted.

46. P. Ackerman, C. V. C. Glover and N. Osheroff, J. Biol. Chem. 263, 12653 (1988). 